Approaches to the Medieval Self 



\section{Approaches to the Medieval Self}

Representations and Conceptualizations of the Self in the Textual and Material Culture of Western Scandinavia, c. 800-1500

Edited by

Stefka G. Eriksen, Karen Langsholt Holmqvist, and Bjørn Bandlien 
ISBN 978-3-11-065555-1

e-ISBN (PDF) 978-3-11-065558-2

e-ISBN (EPUB) 978-3-11-066476-8

https://doi.org/10.1515/9783110655582

\section{(cc) BY-NC-ND}

This work is licensed under a Creative Commons Attribution-NonCommercial-NoDerivatives 4.0 International License. For details go to http://creativecommons.org/licenses/by-nc-nd/4.0/.

\section{Library of Congress Control Number: 2020938218}

\section{Bibliographic information published by the Deutsche Nationalbibliothek}

The Deutsche Nationalbibliothek lists this publication in the Deutsche Nationalbibliografie; detailed bibliographic data are available on the Internet at http://dnb.dnb.de.

(C) 2020 Stefka G. Eriksen, Karen Langsholt Holmqvist and Bjørn Bandlien, published by Walter de Gruyter GmbH, Berlin/Boston

The book is published open access at www.degruyter.com.

Cover image: Trilingual compendium of texts, MS Gg 1.1; 490v, reproduced by kind permission of the Syndics of Cambridge University Library.

Typesetting: Integra Software Services Pvt. Ltd.

Printing and binding: CPI books $\mathrm{GmbH}$, Leck

www.degruyter.com 